\title{
BASIC ELEMENTS OF THE FINANCIAL FUNCTION IN BUSINESS ENTITIES
}

\author{
Slobodan Bracanović ${ }^{1}$ \\ DOI: https://doi.org/10.31410/ITEMA.2020.151
}

\begin{abstract}
Finance and accounting are the essences and the lifeblood of the business doing of business entities. Classical financial mechanisms and instruments are adapted to the contemporary conditions of profitable business doing. The real economy is the basis of the financial economy. Public finance is a special field. Virtual, parallel finance is manifested in contemporary business doing.
\end{abstract}

Keywords: Finance, Accounting, Function, Market, Flow, Capital, Virtual.

\section{PRIOR DETERMINANTS}

$\mathrm{F}$ inance, i.e. the financial function (apart from the supply, production and sales functions), is of special and priority significance in all business entities. The financial function of a business entity (an enterprise, a company) is possible to perceive as the flow and process of the management of monetary jobs and tasks, i.e. the collection, accumulation, concentration and securing of financial assets for manufacturing, service, commercial and marketing goals and purposes, and so forth. The financial function is the underpinning for the achievement of financial decision-making (analyses, research studies, business operation and profitable business doing rating and assessment), as well as strategic, tactical and operational decisionmaking, investing - and personnel-related decisions (in the short, medium and long terms), and so forth.

The role, place, and significance of finance in the management system can be perceived in a complex and differentiated manner, bearing in mind a very complex set of factors: manufacturing, capital, a structure, costs and changes, an increase in value; business and financial decision-making; the distribution of own funds; anticipated changes and an increase in monetary flows; the creation and modelling of projections, concepts and strategies; the management of riskiness, a salary (stimulus) payment policy; the estimation and assessment of effects, the results of profitable business doing, and so on. Finance is the lifeblood of the economic mechanism.

Each one of the existing functions in business entities contains and includes the management of the function itself as well. Analogously, there is also the management of the management system itself ("meta management"). The place, role and significance of finance in general management are important. More specifically, apart from general management in the supply, manufacturing and sales functions (enterprises), it is also possible to observe financial management in each one of these individual business functions. Namely, the connectedness between the financial function and goods and monetary flows, on the one hand, and the other functions in the management of business entities crystallizes itself. Circulation and the "circular

1 Faculty of Economics in Priština, Kosovska Mitrovica 
flow of reproduction" is traced from money, goods (raw materials and reproduction materials), manufacturing and goods again (finished products), realized money etc.

The financial goals that can be classified in a principled way into the following groups: initial, interim (interphase and interstate) and final assume special significance. "Initial goals" include the optimal structure of assets and sources of funds, liquidity, rational and purposeful investments. "Interim goals" include financial stability and balance, cost (expense) minimization and the maximization (optimization) of income, revenue and a profit (accumulation), solvency, asset turnover (favoring the speed of such turnover) and so on. Final goals incorporate the financial strength, poser and independence (i.e. autonomy); the maximization of gains and a profit (profitability) as a target function; an increase in property (assets). The structure of said financial goals and the interactive connections existing between them are perceived. The role and significance of these goals achieve both for the financial function and overall management, guidance and decision-making in a concrete business and social, or state (public) entity crystalize themselves. $(6 ; 2015,325-326)$.

\section{THE INTER-CAUSALITY OF FINANCIAL DETERMINANTS}

The connectedness, interdependence and inter-conditionality of financial determinants in business and social entities are perceived bearing in mind the financial goals, organization, policy, concept and strategy, the information system, and decision-making flows.

Diagram 1. The connection of the factors: the financial goals and policy, information and decision-making:

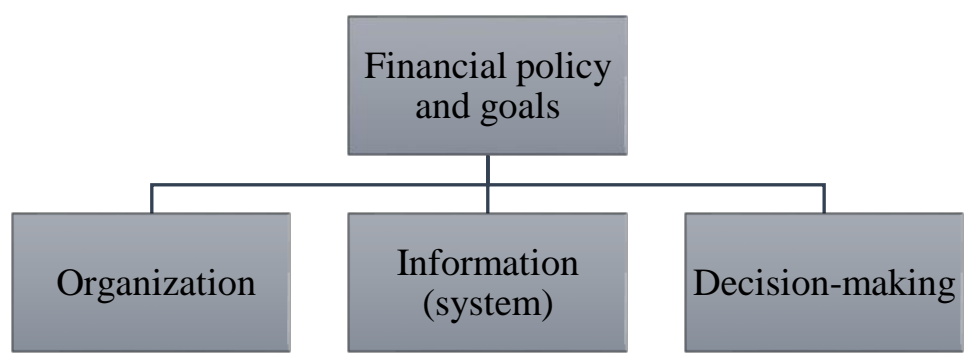

The main, basic tasks of the financial function encompass a panoply including planning the financial assets of profitable business doing, the provision of assets (own, credit, donations, etc.) for all business functions, the use and functional use of assets (inflow and/or outflow dynamics), placement (forms, time, riskiness, anticipated yields) and potential transformations (the circular flow) of assets from one form into another, the collection of realization and claims based upon products and/or services (manufacturing, nonmanufacturing, combined), the monitoring of all the monetary asset flows through the control system (cashier operations, securities received and issued, giro accounts, liabilities and receivables (claims), unfinished production, buyers, suppliers, stocks, interests, insurance, integration, etc.).

There are also derived and accompanying tasks of the financial function that include the recording and control of financial documentation, the financial analysis of business operations (the analysis of the balance, ratio analysis, the analysis of productivity, profitability and cost effectiveness, liquidity, solvency), the payment modality (cash, noncash, etc.), informing, reporting, and so forth. The close connectedness between the bookkeeping-accounting and the financial functions as the "more passive" activity and the "more active" activity, respectively, 
is crystallized; it is quite frequently the case that, in practice, these two functions are performed as one, the so-called financial-accounting function.

The goals and tasks of financial activities indirectly economic, or social and/or state-owned entities, determine constant programming, the designing and planning of diverse activities and actions integrally including diverse balance positions (in the Balance Sheet and the Profit and Loss Account), planning different flows and processes (of cash, total assets, the basic and working funds, i.e. capital, in a contemporary complex interpretation, etc.). For said reasons, the financial function performed in business entities is carried out in connection with the scope, complexity and sophistication of financial tasks, and in compliance with different principles of the organization, such as centralization, decentralization, mixed forms, etc., also depending upon numerous (internal and external) factors, the form of the activity, the technicaltechnological equipment of work and personnel potentials, marketing, etc. and that function is becoming ever-stronger in contemporary conditions. $(6 ; 327-328)$

Diagram 2: The model of the organization of the financial function and jobs in business entities:

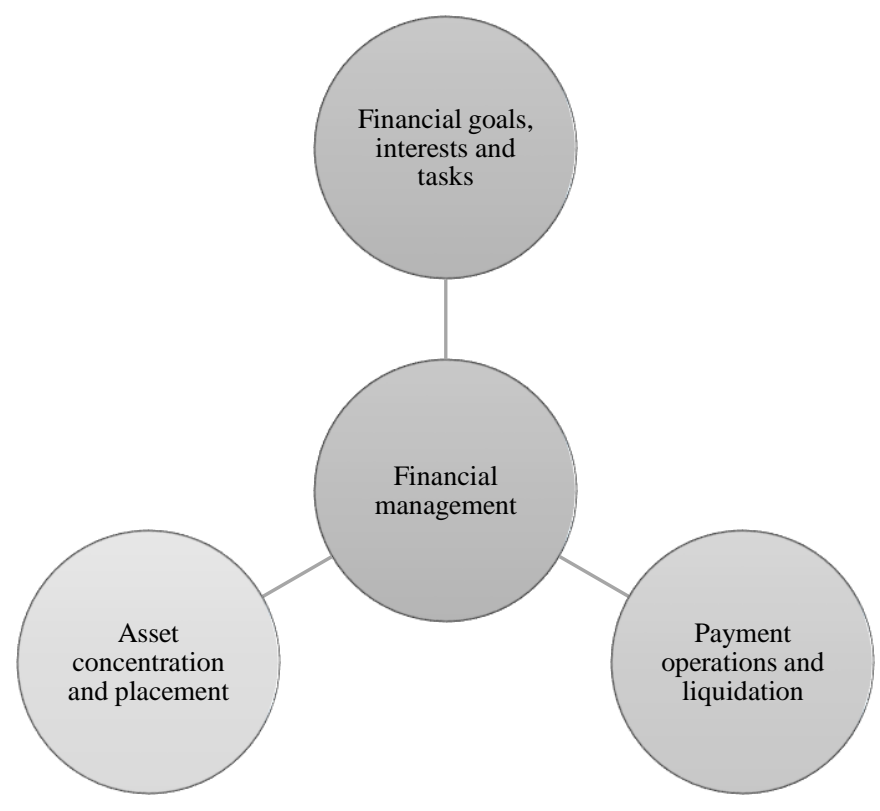

The activities of the raising, collection and placement of assets include financial business operations, (5), making investments in research and development, the activities in the financial market (capital), and asset insurance and channeling activities. Payment operation and liquidation jobs include obligations (liabilities) towards suppliers and receivables from buyers, liquidation ("depot"), cash-in-hand, and so forth. The activities of financial management include planning (the plan), analysis, control and reporting. There are also interim jobs. (6; 328).

The connection between and inter-conditionality, intertwinement and the crisscross nature of the flows and actors in financial planning are indicative, bearing in mind the complex multidimensional, dynamic plan set of factors and elements, such as fixed assets, the stocks of raw materials, materials (reproduction materials), manufacturing in progress, the stocks of finished products, salaries and other costs of labor, amortization, buyers and suppliers, receivable collection, cash flows, sales and administrative costs, cash and loan sales, sales 
assets and purchase assets, investment, shareholders and lenders, the use of loan arrangements, loan placement payoff, dividends, inflationary tendencies and the reality of nominal indicators, and so on. There are cash flows from business, investment activities, funding (collection and payout, asset inflows and outflows). Cash flows are realized as the net changes in cash assets during a business period $(6 ; 329-330)$. Finance and accounting are the very backbone of business operations.

Diagram 3: The principles/rules of financing as the norms of the application of a financial policy

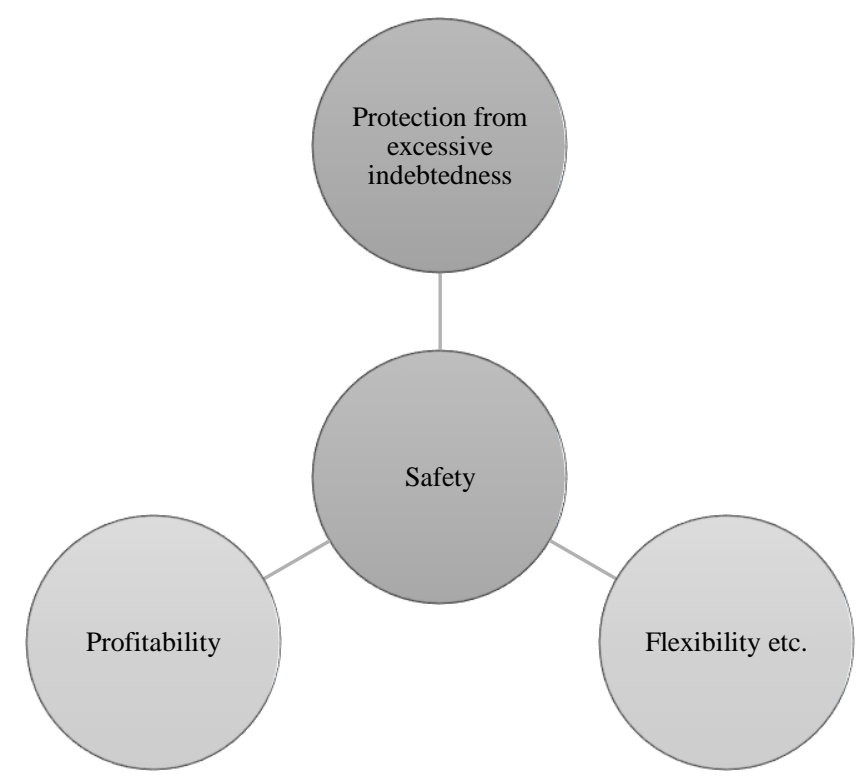

"The Profitability Principle" expresses a positive financial effect, which implies that it expresses optimal, maximum results on a longer- or longtime horizon. "The Safety Principle" assumes that the business from which the spent monetary assets will be valorized with a (relative) certainty are financed. A business entity aspires to a reduction in and the minimization of costs and the strengthening of its own sources of financing (in closing the "funding construction"). The impossibility of the collection of receivables that must necessarily be minimized is also a risk. There are also suspicious and/or disputed receivables. "The Flexibility (Elasticity) Principle" denotes the ability to adapt to changed market and conjunctural conditions quickly or more slowly in a short term. The additional capital conditioned by an increase in the scope of and/or changes in the business operation structure is also a necessity. "The Excessive Indebtedness Protection Principle" implies the funding brought into compliance with riskiness, i.e. the share of own capital necessarily has to be proportional to riskiness, i.e. risk should necessarily be accompanied by a greater share of own capital (with an increase in the share of own capital, the independence and autonomy of a business entity - enterprise also increases). The rules of financing imply norms for the implementation of a financial policy. The financing principles include a) a relationship between own and foreign capital (vertical rules), b) the relationships between parts of assets and capital (horizontal rules), and c) related factors (cross-elements). This is the domain of classical finance. The purport of financial analysis implies offering an information base for the tendencies of the development of the analyzed or investigated phenomenon through the decomposition of phenomenal forms and comparison, all aimed at and for the purpose of decision-making, making correct decisions, and undertaking adequate activities and procedures. The capital market, which is favored in contemporary conditions of profitable 
business doing, denotes the place in which the offer of and demand for capital, (4), i.e. different forms of financial mechanisms and instruments, confront with each other, the place where a larger number of participants (the state, issuers, investors, etc.) appear. The movement flows are uncertain. (6; 329-332).

Public finance and the sources of financing budgetary assets, public income, expenses, shortor long-term capital investments, etc. are a special field.

The contemporary era is also characterized by the existence of parallel and virtual finance, the building of pyramidal and fictitious, nonexistent financial power structures. $(1,2,3)$.

\section{INDIVIDUAL MONETARY FLOWS IN SERBIA}

Certain indicators belonging to the financial, i.e. credit-monetary sphere relevant for profitable business doing in Serbia were indicative for the duration of the prior development period.

Table 1. The crystallized indicators of cash flows and the money supply (in billion dinars):

\begin{tabular}{|l|c|c|c|c|c|}
\hline \multicolumn{1}{|c|}{ Elements } & 2001 & 2007 & 2013 & 2019 & Growth (\%) \\
\hline Primary & 41.643 & 169.020 & 311.159 & 581.717 & 15.78 \\
\hline M1 & 58.233 & 248.873 & 388.265 & 903.603 & 16.46 \\
\hline M3 & 125.414 & 903.871 & $1,716.882$ & $2,823.516$ & 23.43 \\
\hline
\end{tabular}

Source: Ministry of Finance of the Republic of Serbia (May 2020), "The Public Finance Bulletin”, Belgrade, pp. $12-14$.

A fact is established of the dynamic nominal growth of the primary money in the domestic (dinar) currency (at an average annual long-term growth rate of $15.78 \%$ ). There is also a dynamic trend of the growth of the money supply (M1) at the synchronous rate of $16.46 \%$ ). Apart from this, the money supply (M3) achieves the most dynamic growth (at the rate of $23.43 \%$ ). It is necessary to point out the existing inflationary tendencies affecting the reality of the increase in the monetary indicators.

Graph 1: The quantitative parameters of the monetary supply presented graphically

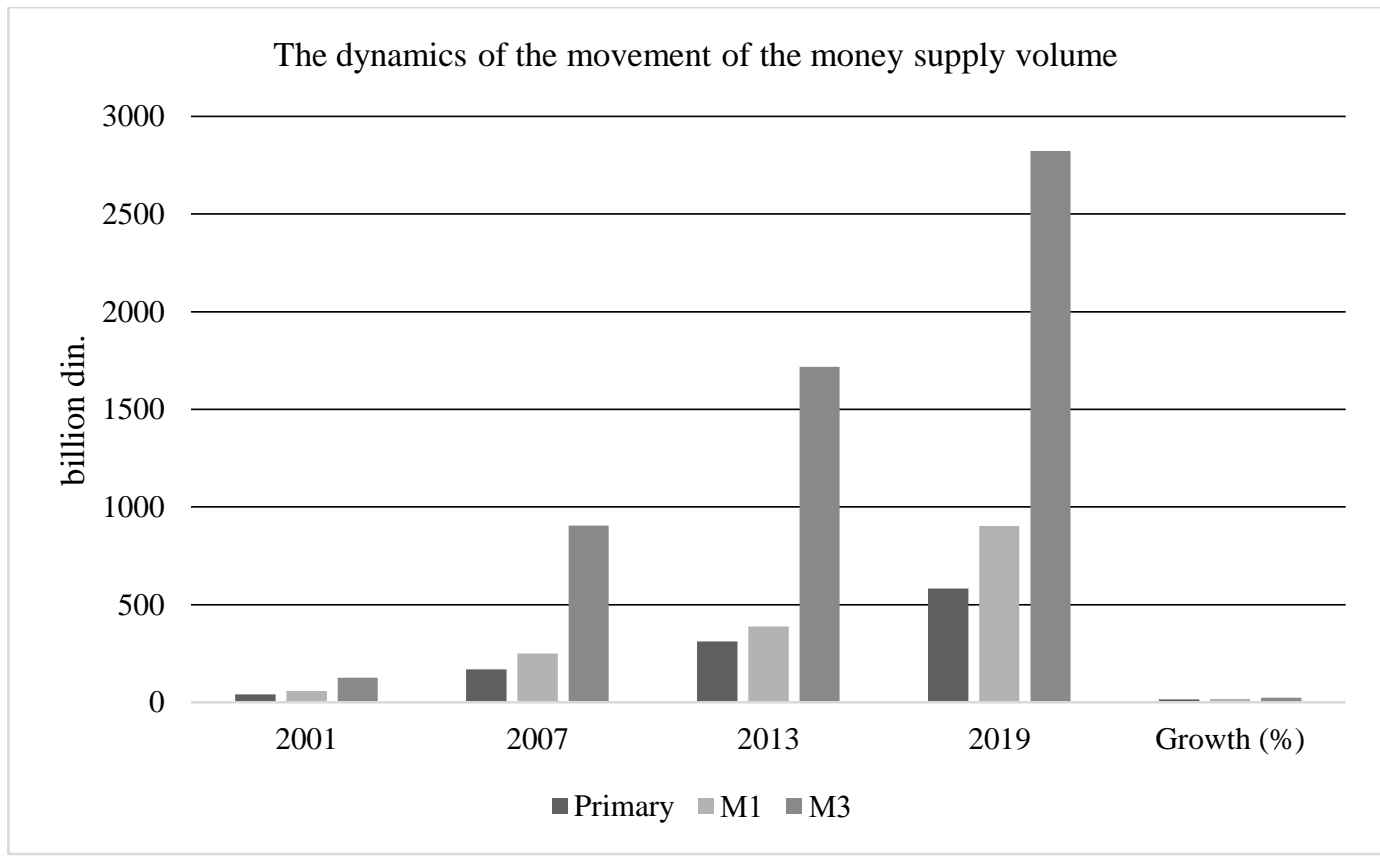


Table 2. The volume of loan placements to the corporate sector and the retail sector (in billion dinars):

\begin{tabular}{|l|c|c|c|c|c|}
\hline E 1 e m e n t s & 2001 & 2007 & 2013 & 2019 & Growth (\%) \\
\hline Corporate sector & 247.829 & 508.167 & $1,110.016$ & $1,290.788$ & 9.60 \\
\hline Retail sector & 5.277 & 305.967 & 673.696 & $1,111.392$ & 219.17 \\
\hline Total $(1+2):$ & 253.106 & 814.134 & $1,783.712$ & $2,402.180$ & 13.32 \\
\hline
\end{tabular}

Source: Ministry of Finance of the Republic of Serbia (May 2020), "The Public Finance Bulletin", Belgrade, pp. $12-14$.

It is possible to perceive the dynamic long-term growth of financial loan placements (arrangements) to the institutional (individual) corporate and retail sectors, and in the total volume as well. The most dynamic growth is achieved by the loan assets directed with a special purpose towards the retail sector. Again, it is needed to highlight the inflationary trends affecting a reduction in the real value of the nominal parameters in this period. Inflation (expressed by the retail consumer price growth rate) was on average $91.8 \%$ and $1.7 \%$ in 2001 and 2019, respectively. In the latest available period (May 2020), inflation was reduced $(0.7 \%$ at the interannual level), and this trend was significantly affected by the movement of the oil derivative prices. Synchronously, the comparative inflation of the EU countries is lower $(0.6 \%)$.

Graph 2. Clearer presentation of the loan volume numerical parameters

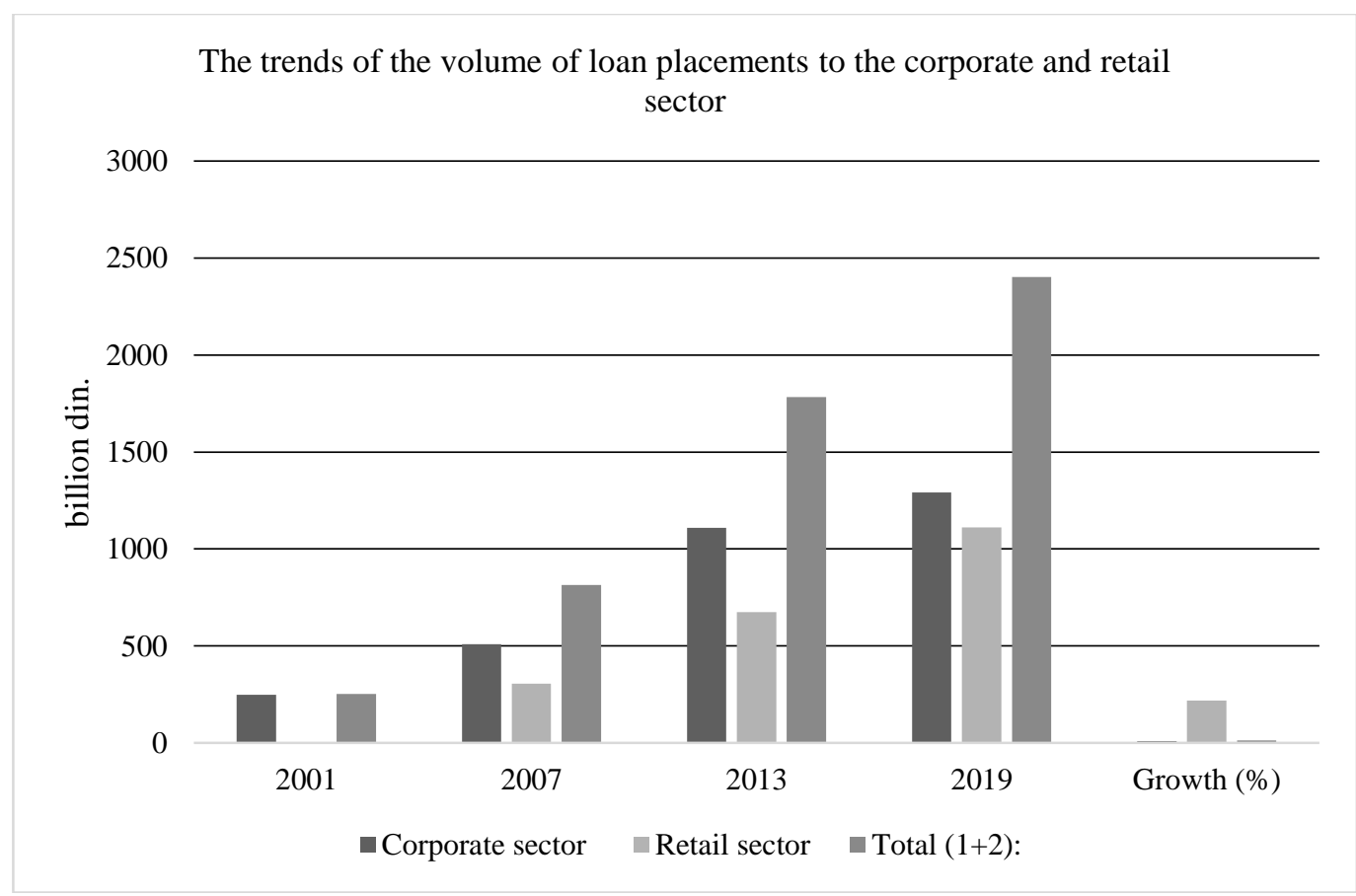

In the current period, the biggest formative share in the structure of the placements to the corporate sector was achieved by loans for working assets $(38.9 \%)$ and investment loans $(43.3 \%)$, with the interannual growth of the working asset loans (12.2\%) and investment loans (24.5\%). Comparatively, when the placements to the retail sector are concerned, the biggest structural share was achieved by cash loans (43.8\%) and residential loans $(36.3 \%)$, with the interannual growth of cash loan assets (16.5\%), as well as residential loan arrangement $(6.4 \%)$. 
Regarding the structure of the sources of the bank assets, the share of the assets lent dominates (85.3\% at the end of May 2020). Comparing that with the same period of the previous year, the lent assets increased (1.4\%). The structure could also be substantially more favorable.

From the aspect of the currency structure of the asset sources, too, the foreign-exchange sources prevail, participating with a share exceeding one-half $(50.6 \%)$; however, the share was reduced in comparison with the identical period of the last year $(1.9 \%)$, which is the question of the optimality of the share of the domestic sources.

The "inflow of (foreign-exchange) assets" was also achieved by issuing state (public) bonds in the international financial market to accomplish operational goals.

The money supply was covered (M1, 159\%) even considerably more than the half-year imports. In May 2020, the NBS retained the level of the reference interest rate (1.5\%). The movements in the foreign exchange market are a determinant of the real depreciation of the domicile currency in comparison with the EUR currency $(0.1 \%)$, whereas nominally, the Dinar did not fluctuate. In comparison with the same period in the last year, the foreign-exchange rate achieved a nominal appreciation $(0.3 \%)$ and a real appreciation $(0.9 \%)$. With the aim of amortizing enormous current oscillations, the financial institution, i.e. the NBS, intervened at the interbank foreign-exchange market with a greater amount of money (i.e. 250 million euros) in May 2020.

Banks are also the largest individual investors in state securities.

Speaking about financial markets, the trade of securities, stocks and bonds was reduced by onethird in May 2020 in relation to the same period in 2019 on the Belgrade Stock Exchange. Furthermore, the total market capitalization at the end of May 2020 was considerable (510.1 billion dinars); however, it was reduced by $2.6 \%$ in comparison with the identical period in 2019. Besides, this year in May, foreign investors did not have a big share in the total turnover on the Stock Exchange (6.15\%), the same being reduced by $7.25 \%$ in comparison with the same period in 2019. The share of foreign investors in trade flows and stocks was synchronously significant $(28.74 \%$, with a comparable growth of $18.59 \%)$, whereas this share in the trade of the public bonds of the RoS was smaller (4.17\%, with a comparable significant reduction 10.30\%). The oil price (for the Urals oil type) was over 30.65 dollars/barrel, and the price has been reduced by $41.7 \%$ since the beginning of 2020 in comparison with the same period in the previous year $(7 ; 7-10)$.

\section{CONCLUSION}

Finance and accounting are the backbone, depth and "lifeblood" of the business operations of a business entity. Financial goals and principles have theoretically and practically been elaborated. Namely, for example, the liquidity principle shows whether a business entity in capable of valorizing (i.e. paying for) its liabilities that have come due and payable simultaneously maintaining the necessary volume and/or structure of working (monetary and other) assets and maintaining a solid "credit rating, i.e. financial reliability".

The financial indicators of activities are expressed by the relations of the total income and costs, individual and total investments in business assets, and so on. These relations represent the coefficients of the turnover of such business (basic and working) assets (which can be different). A financial constellation is denoted by the ownership structure of the source of 
assets. This structure has a goal to perceive the proportion of own and borrowed sources of financing. The indicators of the market value are indicative for enterprises (especially so for joint-stock companies), and they encompass the indicators of the market price per share, net earnings per share, dividends and so on.

Efficiency is reduced to the "minimax" principle, i.e. the principle implying minimum investment and maximum effects. The real economy is the basic of the financial economy. "Virtual finance" is the contemporariness.

\section{REFERENCES}

Bulatović M. (2004), Pravila ćutanja, Narodna knjiga, Alfa, Beograd;

Bulatović M. (2011), Ekonomija i demokratija - Držati glavu iznad, Jumedia Mont, Podgorica; Bulatović M. (2018), Nevidljivi lanci - Moć nepostojećeg novca, Laguna, Beograd;

Dragutinović D., Filipović M., Cvetanović S. (2005), Teorija privrednog rasta i razvoja, Centar za izdavačku djelatnost Ekonomskog fakulteta u Beogradu, Beograd;

Jančetović M., Đurić Z. (2005), Strategijski i operativni menadžment, Beogradska poslovna škola, Beograd;

Mašić B., Dželetović M. (2015), Uvod u menadžment, Inovacioni centar fakulteta bezbjednosti Univerziteta u Beogradu, Akademska knjiga, Novi Sad, Beograd;

Ministarstvo finansija Republike Srbije (maj, 2020), Bilten javnih finansija, Beograd, str. 7-14. 